ADVANCES IN EXPERIMENTAL MEDICINE AND BIOLOGY

Volume 337

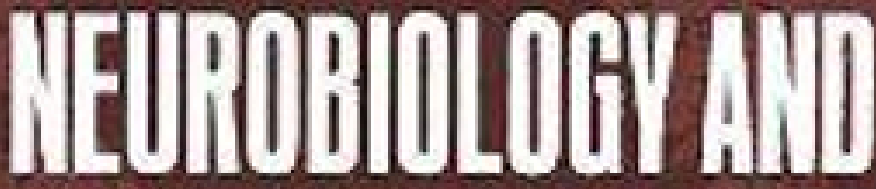 \\ BEL PHNSOLLONY OF BIEMDIREEPTIOK
}

Edited by P. G. Data, H. Acker, and S. Lahiri 


\section{$21 \mathrm{Ca}^{2+}$ DYNAMICS IN CHEMORECEPTOR CELLS: AN OVERVIEW}

\section{González, J.R. López-López, A. Obeso, A. Rocher, and J. García -Sancho}

Dpto. Bioquímica y Biología Molecular y Fisiología, Facultad de Medicina, Universidad de Valladolid, 47005 Valladolid, Spain

The carotid body (CB) was defined as a sensory organ by De Castro in 1928. Two years later, Heymanns and coworkers demostrated that the organ was sensitive to alterations in blood gases and $\mathrm{pH}$, in such a way that a decrease in blood $\mathrm{PO}_{2}$ or $\mathrm{pH}$ or an increase in blood $\mathrm{PCO}_{2}$ produced activation of the $\mathrm{CB}$ and, reflexely, hyperventilation. De Castro postulated that glomus cells were the sensor structures and that they should release some substance to transmit the stimulus to the sensory nerve endings (De Castro, 1928). De Castro's point of view, was widely accepted, and therefore the CB was considered a secondary sensory receptor. As a consequence, the principal aims of many workers in the chemoreception field have been to define the nature of the sensing mechanims ( sensory transduction process ) and to identify the substances released by chemoreceptor cells.

The initial experimental approaches to these questions were based on the use of "in vivo" preparations. The physiological role of CB in systemic reflexes was established and the "in vivo" preparation led also to some hypothesis about the sensory transduction process. The metabolic and the acidic hypothesis were developed (Fidone and Gonzalez 1986). However, the truly intimate functional aspects of the chemoreception process remained undefined. It becamenecessary to look for alternative experimental approaches, and an elegant "in vitro" preparation was developed by Eyzaguirre and Lewin in 1961. However Eyzaguirre's preparation was not well accepted; the results obtained in "in vitro" preparations were criticized, arguing that the CB was not functional or that it was dead (see discussion in Torrance, pp. 248 and 298 and in Acker et al., 1977 pp. 76-77). General acceptance of the preparation had to await until the seventies, when Whalen and Nair (1976) and Starlinger and Lübbers (1976) demostrated that the CB "in vitro" exhibited $\mathrm{PO}_{2}$ levels and $\mathrm{O}_{2}$ consumption rates very similar those found "in vivo". Ultrastructural analysis of the CB after "in vitro"superfusion showed excellent preservation of the tissue (Verna et al., 1981). The "in vitro" preparation offered a well controlled system to study basic mechanisms, including neurotransmitter synthesis and release.

In the later sixties, a considerable background existed in the field of neurotransmission and secretion in general. Katz and Miledi (1965) had demostrated the role of $\mathrm{Ca}^{2+}$ in the release of acetylcholine in the neuromuscular junction. Studies performed in the adrenal medulla led to similar results and to the proposal of the concept of stimulus-secretion coupling by Douglas in 1968. In this scheme, acetylcholine would produce an increase in membrane permeability, an influx of $\mathrm{Ca}^{2+}$ and the secretion of catecholamines. Douglas viewed stimulus-secretion coupling as a general concept, that should be common to many different cells; the differences would be the nature of the stimulus and of the released substances. Secretion studies carried out in other preparations as neurohypophysis 
submaxillary gland or mast cells confirmed Douglas's theory. Sensory synapses should display similar properties, and therefore, chemotransduction in the $\mathrm{CB}$ should be considered as a particular case of stimulus-secretion coupling.

The first studies about the role of $\mathrm{Ca}^{2+}$ in chemotransduction process appeared in the Symposium on Arterial Chemoreceptors held in Oxford in 1966 (Eyzaguirre and Zapata, 1968). At that time, the idea that chemoreceptor nerve endings were stimulated by some substance released by chemoreceptor cells was prevalent. There was not agreement about the identity of the neurotransmitter, but acetylcholine and catecholamines were the two candidates at hand. In that meeting, Eyzaguirre and Zapata showed, using the "in vitro" preparation that the $\mathrm{CB}$ output (carotid sinus nerve discharges) was indeed $\mathrm{Ca}^{2+}$ dependent. Bathing the $\mathrm{CB}$ in $\mathrm{Ca}^{2+}$-free solutions prevented the $\mathrm{CB}$ to respond to hypoxia, acidity or interruption of flow. These results should indicate, according to the stimulus-secretion coupling theory, that $\mathrm{Ca}^{2+}$ was necessary to release some substance from chemoreceptor cells during stimulation. In 1973, in the Bristol meeting, Eyzaguirre (Eyzaguirre, Fidone and Nishi, 1975) confirmed the role of $\mathrm{Ca}^{2+}$ studying, also in the "in vitro" preparation, the generation of mass receptor potentials. He showed that acetylcholine was unable of reversing the receptor blockade produced by $\mathrm{Ca}^{2+}$-free solutions, a finding that should be considered contrary to the notion that acetylcholine was the transmitter between chemoreceptor cells and nerve endings

This research program, which tacitly settled CB function in the context of stimulussecretion coupling theory, suffered an unfortunate drawback in the early seventies. Biscoe and coworkers repeated De Castro's degeneration experiments and found that nerve endings in synaptic contact with glomus cells were efferent. Therefore glomus cells should be glandular cells activated by their secretomotor innervation. The chemoreceptor structures should be a very fine sensory fibers present between sustentacular cells (Biscoe, 1971). However, although this theory prevailed during almost a decade, the chemoreceptor nature of chemoreceptor cells was re-established with different approaches by many laboratories (for a detailed discussion see Fidone and Gonzalez, 1986). In the early eigthies Fidone and coworkers demostrated, using an "in vitro" preparation of rabbit $\mathrm{CBs}$, that hypoxic stimulation activated synthesis and release of dopamine in proportion to the stimulus intensity, and that the release was highly dependent on extracellular $\mathrm{Ca}^{2+}$ (Fidone et al., 1982a, 1982b). These results supported clearly the original point of view considering chemotransduction as a particular case of stimulus-secretion coupling.

Keeping this idea in mind, Gonzalez's group has performed a large series of neurochemical experiments directed to check the role of $\mathrm{Ca}^{2+}$ in the chemotransduction process. The experiments were designed with a double aim: first, it should be demonstrated that dopamine was released in proportion to the intensity of every stimuli; second, it should be demonstrated that the stimulus-induced release was $\mathrm{Ca}^{2+}$-dependent. These two premises imply that the release response was a valid index of chemoreception and also a valid index of $\left[\mathrm{Ca}^{2+}\right]_{j}$ (Baker and Knight, 1984). Rigual et al. (1984, 1986 and 1991) demostrated that the cat $\mathrm{CB}$ "in vitro" was able to synthetize dopamine and to release it in response to acidic and hypoxic stimulation, and that the amount of dopamine released was proportional to the intensity of stimulus and paralleled by the frequency of sensory discharges. They also showed that hypoxic-and acid-induced release of dopamine was strongly dependent of extracellular $\mathrm{Ca}^{2+}$. A typical experiment of $\mathrm{Ca}^{2+}$-dependence of hypoxic stimulus-induced release is shown in figure 1A. Simultaneously, Almaraz et al. (1986) found that extracellular high $\mathrm{K}^{+}$was a very powerful stimulus for the cat $\mathrm{CB}$ promoting a great release of dopamine and that the effect of $\mathrm{K}^{+}$was also mediated by extracellular $\mathrm{Ca}^{2+}$. 
A typical experiment showing the $\mathrm{Ca}^{2+}$ dependence of high $\mathrm{K}^{+}$-induced release of dopamine is showed in figure 1B. It was known (Kirpekar and Prat, 1979; Kikodoro and Richie, 1980) that $\mathrm{K}^{+}$induced neurotranmitter release by depolarizing the secretory cells and promoting $\mathrm{Ca}^{2+}$ entry through voltage-dependent channels. Therefore, Almaraz's results demostrated two important aspects of chemoreceptor cell function. Firstly, they established that membrane potential of chemoreceptor cells should be dependent of $\mathrm{K}^{+}$ a notion questioned up to the middle eighties, and secondly, they strongly supported the existence of voltage dependent $\mathrm{Ca}^{2+}$ channels in these cells.

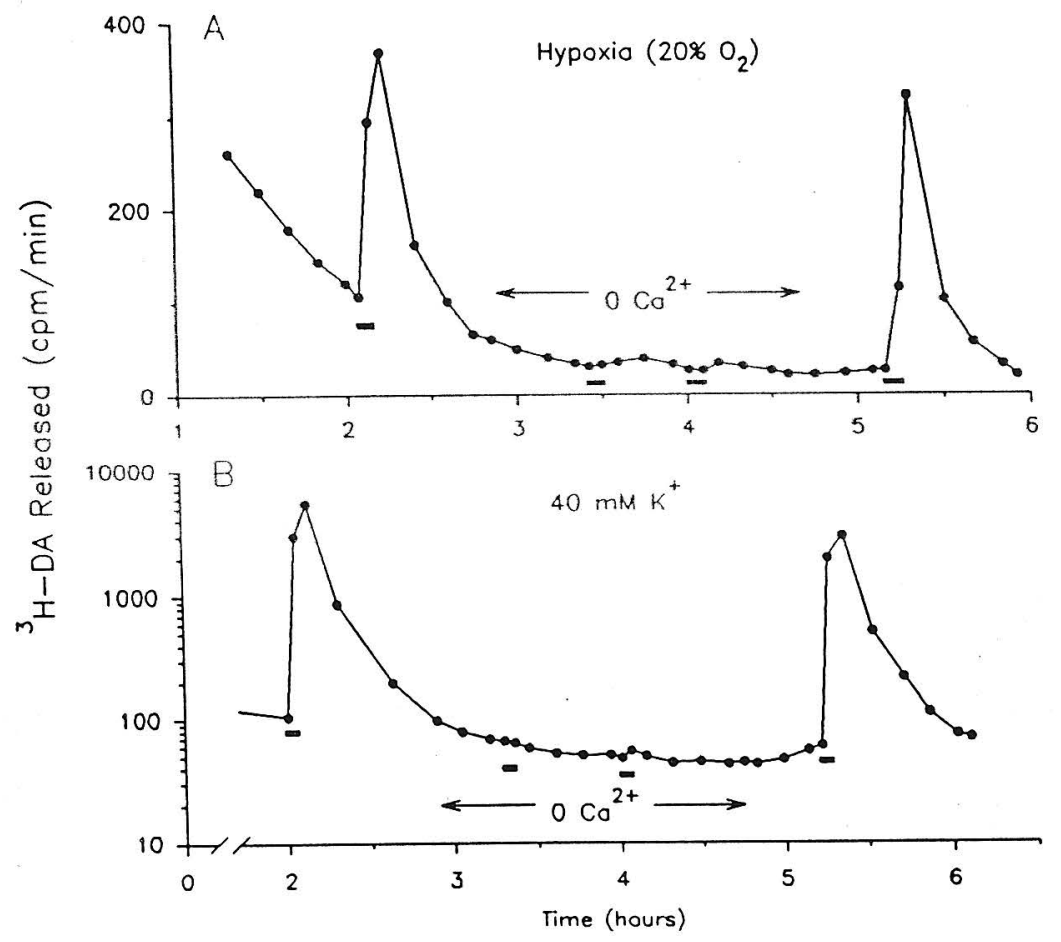

Fig.1. $\mathrm{Ca}^{2+}$ dependence of the ${ }^{3} \mathrm{H}$-dopamine induced release. The time course of the release of ${ }^{3} \mathrm{H}$-dopamine from two different cat carotid prelabelled with ${ }^{3} \mathrm{H}$-tyrosine are shown. In (A) hypoxia $\left(20 \% \mathrm{O}_{2}\right.$ control $\left.100 \% \mathrm{O}_{2}\right)$ and in $(B)$ High $\mathrm{K}^{+}(60 \mathrm{mM})$ were applied at horizontal bars. $\mathrm{Ca}^{2+}$ free media was used during the marked time. Taken from Rigual's Doctoral Thesis, 1984 (A) and from Almaraz's Doctoral Thesis, 1983 (B).

As the stimulus-secretion coupling theory predicted, all the known stimuli of the $\mathrm{CB}$ were able to produce release of dopamine in a $\mathrm{Ca}^{2+}$-dependent manner (Obeso et al., $1986,1989)$. The release was always proportional to the intensity of stimulus, and the frequency discharges of carotid sinus nerve increased in parallel to the increase release of dopamine. This parallelism disappeared in $\mathrm{Ca}^{2+}$-free solutions. In this conditions, 
different stimuli augmented sensory discharges by about half of that seen in control $\mathrm{Ca}^{2+}$ containning solutions, but the release of dopamine was reduced by $80-95 \%$. Fidone et $a l$. (1982b) explainned this lack of parallelism using the hazy concept of "a great synaptic safety factor" in the aminergic synapses. In fact, it was known that the affinity of dopaminergic antagonists diminished in $\mathrm{Ca}^{2+}$-free solutions (Van Buskirk and Dowling, 1982) and that the effects of neurotransmitters were also stronger in $\mathrm{Ca}^{2+}$-free media (Kanno et al., 1976; Kato and Narashami, 1982).

It was clear that extracellular $\mathrm{Ca}^{2+}$ was necessary for dopamine release. Therefore, the understanding of the transduction process itself could go a step further if we were able of understand the cellular mechanisms involved in the influx of $\mathrm{Ca}^{2+}$ during stimulation. The existence of voltage-dependent $\mathrm{Ca}^{2+}$ channels was confirmed by Obeso in 1984 in her Doctoral Thesis ( see Obeso et al ., 1987) . She tested the effects of Nitrendipine $0.5 \mathrm{mM}$ (a specific blocker of L-Type voltage dependent $\mathrm{Ca}^{2+}$ channels) on dopamine release induced by hypoxia, high $\mathrm{K}^{+}$and hypercapnic acidosis, using an "in vitro" preparation of cat $\mathrm{CB}$. The results are shown in figure 2 .

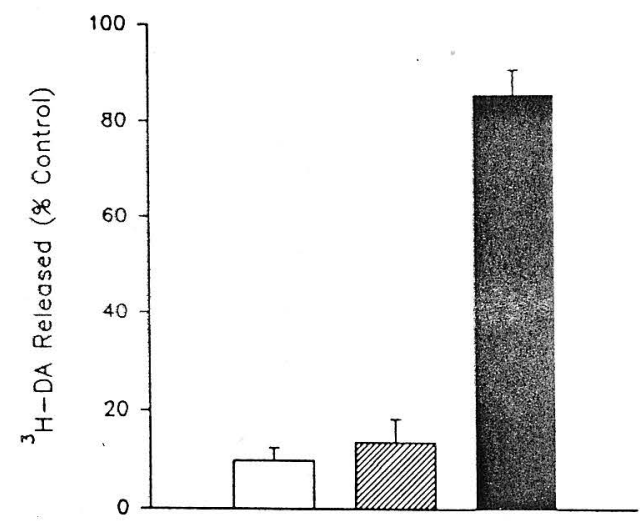

Fig. 2. Effects of Nitredinine (O.5 $\mathrm{mM})$ on ${ }^{3} \mathrm{H}$ dopamine release from cat carotid body induced by $60 \mathrm{mM} \mathrm{K}^{*}$ (open bar), $20 \% \mathrm{O}_{2}$ (crossedbarland $20 \% \mathrm{CO}, \mathrm{pH} 6.8$ (filled bar). Contol wolution was $95 \% 0,5 \%$ CO. Data are meart $+S E M, n=4$. Taken from Obeso's Doctoral Thesis, 1984.

Hypoxic and high- $\mathrm{K}^{+}$-induced release were inhibited by nitrendipine by almost a $90 \%$ suggesting that hypoxia, as high $\mathrm{K}^{+}$, depolarize chemoreceptor cells in order to activate the voltage dependent $\mathrm{Ca}^{2+}$ channels. Similar results for hypoxic stimulation were obtained by Shaw et al. (1989) measuring ${ }^{45} \mathrm{Ca}$ fluxes. On the contrary, acidic stimulus induced release was unaffected by nitrendipine. These findings indicated that, although as already mentioned acidic stimulus induced release was $\mathrm{Ca}^{2+}$ dependent, $\mathrm{Ca}^{2+}$ did not enter the cells through $\mathrm{Ca}^{2+}$ channels. Therefore, the mechanisms involved in the transduction of hypoxic and acidic stimuli seem to be different and other pathways for $\mathrm{Ca}^{2+}$ entry, different than voltage dependent $\mathrm{Ca}^{2+}$ channels, had to be investigated (see below).

Rocher in 1989 in her Doctoral Thesis ( see Obeso et al ., 1992) expanded Obeso's results in a "in vitro" preparation of rabbit $\mathrm{CBs}$, testing the effects of different dihidropyridines (BayK 8644 or Nisoldipine) and inorganic blockers of $\mathrm{Ca}^{2+}$ channels $\left(\mathrm{Cd}^{2+}\right.$ or $\mathrm{Co}^{2+}$ ) on dopamine induced release. They demostrated also the presence of $\mathrm{Na}^{+}$channels in chemoreceptor cells studying the effects of veratridine and tetrodotoxin on release of dopamine ( Rocher et al ., 1988 ).

Direct verification of the existence of voltage dependent channels has been obtained with the patch clamp tecnique in different laboratories using isolated chemoreceptor cells from different animal species. $\mathrm{Ca}^{2+}$ currents with properties of Ltype channels have been described in isolated cells from adult rabbit (Duchen et al., 1988; 
Ureña et al., 1989), neonatal rabbit (Hescheler et al., 1989) and neonatal rats (Peers, 1990). The hypothesis of hypoxic induced depolarization gained also support from patch clamp experiments. López-Barneo et al. ( 1988 ) identified in chemoreceptor cells a $\mathrm{K}^{+}$ current selectively inhibited on lowering $\mathrm{PO}_{2}$ in the bathing solution. It was also observed an increase in action potentials firing frequency of chemoreceptor cells during low $\mathrm{PO}_{2}$ stimulation and it was proposed a cause-effect relationship between low $\mathrm{PO}_{2}, \mathrm{~K}^{+}$current inhibition and the increase in firing frequency (López-López et al., 1989). Hypoxic $\mathrm{K}^{+}$ current inhibition has been confirmed by other authors, although there are species and age-related differences in the nature of the $\mathrm{K}^{+}$channels inhibited (Hescheler et al., 1989; Peers, 1990; Stea and Nurse, 1991).

A

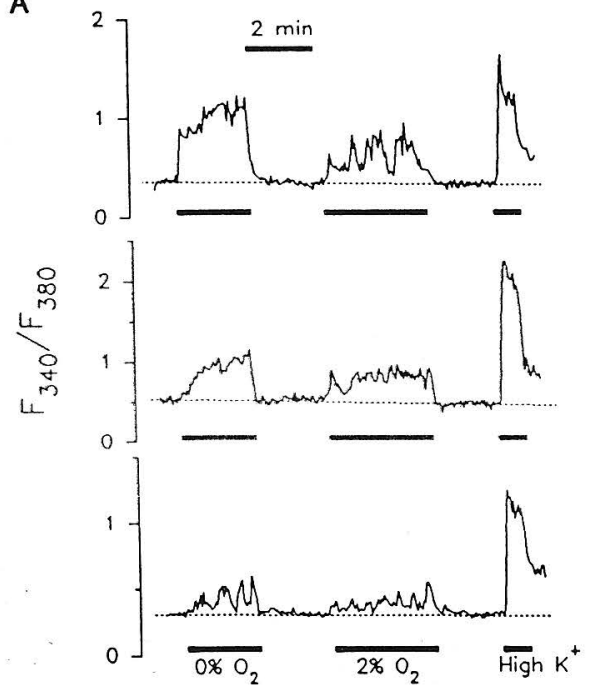

B

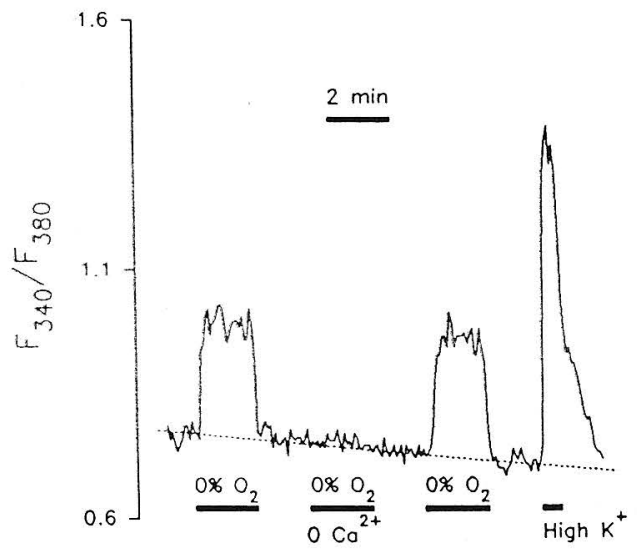

Fig. 3.Intracellular $\mathrm{Ca}^{2+}$ variations under hypoxic and high $\mathrm{K}^{+}$stimulation of chemoreceptor cells isolated from adult rabbit carotid body. $\mathrm{Ca}^{2+}$ levels are represented as the ratio of the fluorescences obtained at 340 and $380 \mathrm{~nm}$ in single cells loaded with fura-2. (A) shows the time course of the intracellular $\mathrm{Ca}^{2+}$ level in three different cells stimulated with anoxia, $2 \% \mathrm{O}_{2}$ and $60 \mathrm{mM} \mathrm{K}^{+}$. $(\mathrm{B})$ shows the extracellular $\mathrm{Ca}^{2+}$ dependence of $\mathrm{Ca}^{2+}$ increase induced by anoxic stimulation in a different chemoreceptor cell.

A new experimental approach to the study of changes in cytosolic $\mathrm{Ca}^{2+}$ during stimulation in isolated chemoreceptor cells is now available. Computer assisted image analysis allows to quantify modifications in intracellular $\mathrm{Ca}^{2}+$ in single cells using fluorescent dyes as fura-2. Figure $3 \mathrm{~A}$ shows the relative intracellular $\mathrm{Ca}^{2}+$ levels in three different cells during normoxia and two intensities of hypoxic stimulation, anoxia and $2 \% \mathrm{O}_{2}$-equilibrated media. It can be seen that hypoxia increased the intracellular $\mathrm{Ca}^{2+}$ in a dosis-dependent manner. In some cells, during hypoxia the intracellular calcium levels showed an oscillatory behavior. The increase in calcium induced by high extracellular potasium is shown at right. The cell response was fast in onset and was mantained during the 30 seconds of high $\mathrm{K}+$ superfusion. Figure $3 \mathrm{~B}$ shows the modifications in intracellular $\mathrm{Ca}^{2}+$ during hypoxia both in the presence and in the absence of $\mathrm{Ca}^{2}+$ in the bathing media. 
In $\mathrm{Ca}^{2+}$-free media hypoxia was not able to change intracellular $\mathrm{Ca}^{2+}$. These data, although very preliminar, confirmed the neurochemical observations described above. Using similar experimental approaches (i.e. patch clamp and intracellular $\mathrm{Ca}^{2+}$ imaging), however, Biscoe and coworkers obtained different results, postulating different hypoxic transduction mechanisms. Briefly, they postulated that mitochondria should be both, the sensor structure and the source of $\mathrm{Ca}^{2+}$ to increase cytosolic $\mathrm{Ca}^{2+}$ levels. A full discussion comparing both, the plasma membrane and the mitochondrial models, could be find in Biscoe and Duchen (1990) and in Gonzalez et al. (1992).

As it has been mentioned above, acidic transduction seems to involve different mechanisms. Rigual et al. (1991) had shown that the effective stimulus during both metabolic or respiratory acidosis were the changes in intracellular $\mathrm{pH}$. Rocher et al. (1991), using the secretory response as a measure of intracellular $\mathrm{Ca}^{2+}$ levels, investigated the pathways for $\mathrm{Ca}^{2+}$ entry into the cells under acidic stimulation. Dopamine release induced by acidic stimuli was dependent on extracellular $\mathrm{Na}^{+}$and $\mathrm{Ca}^{2+}$, and it was also inhibited to a great extent by $\mathrm{Na}^{+} / \mathrm{H}^{+}$exchanger blockers, as amiloride or EIPA, and by bicarbonate reduction and $\mathrm{Cl}^{-}$removal from the bathing solution. These results led to the proposal of a model for acidic transduction in which the coupled activation of different antiporters would produce the required increase in intracellular $\mathrm{Ca}^{2+}$ to elicit neurotransmitter release. The existence of these antiporters has been confirmed with direct measurements of intracellular $\mathrm{Ca}^{2+}$ and $\mathrm{pH}$ by other groups (Biscoe et al., 1989; Buckler et al., 1991). Results obtained with these tecniques (Sato et al., Buckler et al. and Vaughan-Jones et al., present meeting), or in a "in vitro" preparation of cat CB, measuring nerve discharges (Iturriaga and Lahiri, present meeting) are also consistent with the fundamental aspects of this model.

Departing from the last sixties, these have been explained many aspects of the role of $\mathrm{Ca}^{2+}$ in the special stimulus-secretion coupling that represents the chemotransduction process. However, there is not yet a general agreement about $\mathrm{Ca}^{2+}$ routes and dynamics in chemoreceptor cells and a lot of questions have to be solved experimentally in the next years. Among others, aspects such as the role of $\mathrm{Ca}^{2+}$ present in intracellular stores and the nature of the stimulus that induce its release, the role of second messengers modulating the $\mathrm{Ca}^{2+}$ entry pathways, the antiporters or the release of $\mathrm{Ca}^{2+}$ from intracellular stores should be studied.

\section{ACKNOWLEDGEMENTS}

Thanks to María de los Llanos Bravo for technical assistance. Work supported by grants DGICYT 89/0358 and Junta de Castilla y León 1102/89.

\section{REFERENCES}

Acker, H.,Fidone, S., Pallot, D., Eyzaguirre, C.,Lübbers, D.W., andTorrance, R.W., 1977, eds., "Chemoreception in the Carotid Body".

Almaraz, L., Gonzalez, C., and Obeso, A., 1986, Effects of high potassium on the release of ${ }^{3} \mathrm{H}$-dopamine from the cat carotid body in vitro, J. Physiol., 379:293.

Baker, P.F., and Knight, D.E., 1984, Calcium control of exocytosis in bovine adrenal medullary cells, TINS, $4: 120$. 
Biscoe, T.J., 1971, Carotid body: structure and function. Physiol. Rev., 51:427.

Biscoe, T.J., and Duchen, M.R. 1990, Cellular basis of transduction in carotid chemoreceptors, Am. J. Physiol., 258:L271.

Biscoe, T.J., Duchen, M.R., Eisner, D.A., O'Neill, S.C., and Valdeolmillos, M., 1989, Measurements of intracellular $\mathrm{Ca}^{2+}$ in dissociated type I cells of the rabbitcarotid body, J. Physiol. 416:421.

Buckler, K.J., Vaughan-Jones, C., Peers, C., and Nye, P.C.G., 1991, Intracellular pH and its regulation in isolated type I carotid body cells of the neonatal rat, J.Physiol., 436:197.

De Castro, F., 1928, Sur la structure etl'innervation du sinus carotidiende l'homme et des mammifères. Nouveaux faits surl'innervation et la fonction du glomus caroticum. Etudes anatomiques et physiologiques, Trab. Lab. Invest. Biol. Univ. Madrid, 25:331.

Douglas, W.W., 1968, Stimulus-secretion coupling: The concept and clues from chromaffin and other cells, Br.J.Pharmacol, 34:451.

Duchen,M.R., Caddy,K.W.,Kirby, G.C.,Patterson, D.L.,Ponte, J., andBiscoe, T.J., 1988, Biophysical studies of the cellular elements of the rabbit carotid body, Neuroscience 26:291.

Eyzaguirre, C., andLewin, J., 1961, Chemoreceptor activity of the carotid body of the cat, J. Physiol. 159:222.

Eyzaguirre, C., and Zapata, P., 1968, A discussion of possible transmitter or generatorsubstances in carotid body chemoreceptors, in: "Arterial chemoreceptors," R.W., Torrance, ed., Blackwell, Oxford.

Eyzaguirre, C., Fidone, S., and Nishi, K., 1975, Recent studies on the generation of chemoreceptor impulses, $\underline{\text { in: }}$ "The Peripheral Arterial Chemoreceptors," M.J., Purves, ed., Cambridge Univ. Press., London.

Fidone, S.J., and Gonzalez, C., 1986, Initiation and control of chemoreceptoractivity in the carotid body, in: "Handbook of Physiology. The respiratory system II," A.P., Fishman, ed., Am. Physiological Society, Bethesda.

Rocher, A., Obeso, A., González, C., and Herreros, B., 1991, Ionic mechanisms for the transduction of acidic stimuli in rabbit carotid body glomus cells, $\mathbf{J}$. Physiol., 433:533.

Rocher, A., Obeso, A., Herreros, B., and Gonzalez, C., 1988, Activation of the release of dopamine in the carotid body by veratridine. Evidence for the presence of voltage-dependent $\mathrm{Na}^{+}$channels in type I cells. Neurosci. Lett. 94:274. 
Shaw, K., Montague, W. \& Pallot, D.J., 1989, Biochemical studies on the release of catecholamines from the rat carotid body in vitro, Biochim. Biophys. Acta., 1013:42.

Starlinger, H., and Lübbers, D.W., 1976, Oxygen consumption of the isolated carotid body tissue (cat), Pflügers Arch., 366:61.

Stea, A., and Nurse, C.A, 1991, Whole-cell and perforated-patch recordings from $\mathrm{O}_{2}$ sensitive rat carotid body cells grown in short- and long-term culture, Pflügers Arch., 418:93.

Torrance, R.W., 1968, ed., “Arterial Chemoreceptors”.

Ureña, J., López-López, J.R., Gonzalez, C., and López Barneo, J., 1989, Ionic currents in dispersed chemoreceptor cells of the mammalian carotid body, J.Gen. Physiol., 93:979.

Van Buskirk,R., andDowling, J.E., 1982, Calcium alters the sensitivity of intact horizontal cells to dopamine antagonists., Proc. Natl. Acad. Sci. USA., 79:3350.

Verna, A., Roumy, M., and Leitner, L.M., 1981, Ultrastructural features of the carotid body after in vitro experiments: correlation with physiological results, J.Neurocyol., 10:659.

Whalen, W.J., andNair, P., 1976, $\mathrm{PO}_{2}$ in the carotid body perfused and/or superfused with cell-free media, J. Appl. Physiol., 41:180. 